\title{
Biochemical blood parameters and mineral metabolism in the adaptive period in the bovine cattle in the conditions of the Voronezh Region
}

\author{
A. V. Vostroilov ${ }^{1}$, I. Y. Ventsova ${ }^{1}$, V. A. Safonov ${ }^{2}$, \\ ${ }^{1}$ Voronezh State Agrarian University named after Emperor Peter the Great, Voronezh, Russia \\ ${ }^{2}$ Vernadsky Institute of Geochemistry and Analytical Chemistry of the Russian Academy of Sciences, \\ Moscow, Russia
}

Received: December 10, 2020. Revised: June 9, 2021. Accepted: July 8, 2021. Published: July 14, 2021.

\begin{abstract}
The study of the process of adaptation of the Belgian breed bovine cattle to the conditions of the Voronezh Region was based on the biochemical blood parameters and mineral metabolism. The experiment included 20 animals divided into four groups (five heads in each group): Group I - covering age heifers, Group II heifers, Group III - first-calf cows a month after calving, Group IV - one-month-old heifers. In some groups, adaptation processes resulted in deviations from the reference values. In Group II, the level of BUN was $4.7 \%$ higher than the norm. In Groups I and IV, the levels of glucose were higher by $\mathbf{7 . 6 \%}$ and $38.5 \%$, respectively. In Groups II and III, ALT levels were higher than the norm by $9.1 \%$; in Group I - by $15.7 \%$. In Group II, the level of AST was higher by $5.8 \%$ in comparison with the norm. The analysis of mineral metabolism showed that the content of iron was lower than the reference values in first-calf cows in Group III and in heifers in Group IV by 14.4 and $10.8 \%$, respectively. In Group II, the content of copper met the upper border of the reference values. In Group IV, it was elevated by $18.2 \%$ in comparison with the norm. The specified deviations indicated the intensification of the metabolic processes during the adaptation of animals to new conditions. The study results showed that the animals of the Belgian breed were capable of adaptation, which provided successful adaptation to new conditions of the Voronezh Region (Russia).
\end{abstract}

Keywords-Adaptation, biochemical blood compositing, mineral metabolism, bovine cattle.

\section{INTRODUCTION}

$\mathrm{T}$ HE development of the Russian agricultural complex is maintained due to the involvement of the imported bovine cattle of highly productive breeds. The main suppliers of bred animals with high genetic potential are Western Europe and Canada. The imported Holstein-Friesian cows are used for the breeding and improvement of local breeds.

The new cattle import aims to obtain the maximum milk yield and quality replacement stock. Besides, a lot of attention is paid to the quality of the obtained products. The main quality parameters are milk fat and protein output.

However, highly productive animals require higher standards of feed quality and veterinary management. Bovine cattle with intensive metabolism is characterized by an expressed sensitivity to even slight changes in the conditions of feeding and handling. In this case, the genetic potential is secondary and the key role in productivity is played by the conditions of handling and provision with nutrients. In other words, to obtain a high yield of products, it is necessary to implement the original technology of handling and feeding or to provide the closest conditions to the ones the animals are used to.

The weak side of breeds of narrow specialization is an unintentional fixation of congenital defects, for example, weak hoof in Holstein breed or narrow pelvis in Belgian breed. The violation of the animal handling culture and lack of regular monitoring of the conditions of animals sensitive to the conditions of handling lead to a decrease in productivity, weakening of the immune system, diseases, and cattle mortality [1]. Adaptation to the new conditions and acclimatization in animals with high production potential is great stress. The most common issues include heat stress that develops in animals when the ambient temperature rises by $2-3^{\circ}$ along with the increase in air humidity. Hot climate requires additional correction of feeding schemes and regimen of cattle $[2,3,4]$. The consequences lead to a decrease in the productivity and growth rate, development of metabolic processes impairments, gynecologic and obstetrics diseases, dystrophic alterations in the internal organs (often the heart and liver), and pathology of digits and hoofs. Animals are often imported in the state of pregnancy, which complicates the process of adaptation by an intense physiological period $[2,5]$.

The stress that animals experience during the process of adaptation because of low or high temperatures, increased 
humidity, or change in the elevation above the sea level leads to the intensification of the process of free radical oxidation, which induces cascade reactions that result in the exhaustion of the antioxidant protective system. Thus, animals develop oxidative stress and metabolic disorders. This condition contributes to the development of the above-mentioned diseases $[6,7]$.

The mortality in imported animals is primarily observed within the first month after calving and occurs because of fat or toxic dystrophy of the liver and dystrophic alterations in the rumen wall. Animals have an elevated concentration of ketone bodies, and decreased levels of hemoglobin and glucose. The cattle lose weight quickly. The autopsy shows typical alterations in the liver. It becomes yellow and gray-yellowish. Its consistency is moderately dense or loose. The hepatic tissue can squash at palpation. Areas of decayed tissue are visible [8]. There were cases of new cattle mortality because of the poor organization of transportation and traumatism in unusual conditions [9].

The time of adaptation varies greatly depending on the characteristic of the breed, differences between the common and new conditions, and individual peculiarities of animals. The genetic background and constitution of animals determine the capacity of adapting and high productivity. The process of acclimatization is easier in cattle with good constitution and mobility of the central nervous activity. The gastrointestinal microflora suitable for new feeding conditions is established faster in young animals. Besides, the production of antibodies to new antigen factors is more efficient. Etiological features, health condition, and the level of productivity indicate a high degree of organism adaptation to new conditions. Common approaches to the evaluation of the adaptive process include the monitoring of the mortality rate, successful insemination, calves output, dynamic of milk productivity, and parameters of milk productivity. Optimal cooperation of the organs, their systems, environmental factors, and a high rate of livestock reproduction indicate good adaptability of animals to external conditions. Long-term observations are used to monitor the degree of adaptation to new conditions in the dynamics of several generations. Unfortunately, the studies on metabolic status show that imported animals are less adapted than animals of Russian selection, which agrees with biological laws on the unity of an organism and environment $[8,10,11]$.

Presently, milk and meat breeds of animals are actively imported in the Central Federal District and Voronezh Region. Normal growth and development that provide high productivity are possible only in the conditions of homeostasis maintenance. Farms that import bovine cattle control the exterior, condition of flesh, respiratory, and cardiovascular systems. To control their physiological wellness, new efficient methods of evaluation of the viability parameters and the level of correspondence to the requirements are developed including the forecasting of the effects of interaction with new conditions [12]. Besides, morphological and biochemical blood assays remain acute. Blood quickly reacts to the changes in the external and internal conditions by altering its qualitative and quantitative characteristics. The studies on the dynamics of leukogram, erythrocyte count, and level of hemoglobin are informative [4, 13]. In the present study, the authors investigated the biochemical composition of blood in Belgian breed animals in the process of adaptation to the conditions of the farm in the Voronezh Region. The monitoring of the condition of health and well-being of the imported cattle is significant because of the intensification of the development of the agricultural complex in the region.

\section{Materials AND Methods}

The objects of the study were Belgian breed animals that belonged to "Novomarkovskoe SPK", Llc located in the Kantemirovskiy District of the Voronezh Region. The experiment included 20 animals divided into four groups (five animals in each group). Group I contained covering age heifers (19 months old) with the mean live weight of $506 \mathrm{~kg}$. Group II included heifers with a live weight of $682 \mathrm{~kg}$. Group III included first-calf heifers a month after calving with a live weight of $690 \mathrm{~kg}$. And Group IV had heifers one-month-old with the mean live weight of $64 \mathrm{~kg}$. The animals were fed according to the accepted zootechnic norms for bovine animals considering the physiological condition and productivity.

Blood for the biochemical assay was taken from animals from the jugular or tail veins in the morning before feeding. During the sampling, the measures of asepsis and antiseptic were followed as well as the principles of humanity to animals specified in the EU directive (86/609/EEC) and the Helsinki declaration. The blood assay was conducted at the facility of the Voronezh Regional Veterinary Laboratory. The following parameters were evaluated: total protein (refractometric method), BUN, creatinine, glucose, bilirubin, cholesterol, ALT, AST (biochemical analyzer "Hitachi-902"), carotene (CarrPrice method in Yudkin's modification), and ketone bodies (qualitative color test). Total calcium, iron, manganese, zinc, and magnesium were established using an atomic absorption spectrometer "Perkin Elmer-703". The obtained data were processed by the methods of mathematical statistics accepted in biological and veterinary studies using the software package "Statistica 6.0" (Statsoft Inc.).

\section{RESULTS AND DISCUSSION}

The functions of blood as a liquid medium include the maintenance of homeostasis and provision of a continuous interaction of metabolic processes observed in tissues and organs. These characteristics depend on different factors. For example, in the case of long-term uniform feeding with a large share of concentrates, the content of proteins and their products change significantly, and the content of proteins and immunoglobulins in newborn calves is lower than in adult animals. In highly productive animals, intensive metabolism results in a higher concentration of protein and residual nitrogen than in animals with lower productivity. Biochemical parameters depend a lot on the breed, season (the content of vitamins and minerals in the serum), and physiological condition. Still, there are no reference values for biochemical blood parameters in certain breeds of the bovine cattle 
established, so the authors used general reference data [14].

The changes in the conditions of handling that include climate, the regimen of activities, and the new scheme of feeding act as stress factors. These factors can cause changes in metabolic processes. In turn, metabolism, which is closely associated with biochemical blood parameters, alters them. The studied parameters are presented in Table 1.

Table 1. Biochemical blood parameters in the Belgian breed of bovine cattle

\begin{tabular}{|c|c|c|c|c|c|}
\hline $\begin{array}{l}\text { Paramet } \\
\text { er }\end{array}$ & $\begin{array}{c}\text { Refer } \\
\text { ence } \\
\text { values }\end{array}$ & $\begin{array}{c}\text { Group } \\
\text { I }\end{array}$ & $\begin{array}{c}\text { Group } \\
\text { II }\end{array}$ & $\begin{array}{c}\text { Grou } \\
\text { p III }\end{array}$ & $\begin{array}{c}\text { Group } \\
\text { IV }\end{array}$ \\
\hline $\begin{array}{l}\text { Total } \\
\text { protein, } \\
\mathrm{g} \%\end{array}$ & $7.2-8.6$ & $\begin{array}{c}7.74 \pm \\
0.33\end{array}$ & $\begin{array}{c}7.56 \pm \\
0.25\end{array}$ & $\begin{array}{c}8.46 \pm 0 \\
.16\end{array}$ & $\begin{array}{c}7.21 \pm \\
0.24\end{array}$ \\
\hline $\begin{array}{l}\mathrm{BUN}, \\
\mathrm{mmol} / \mathrm{L}\end{array}$ & $3.3-6.7$ & $\begin{array}{c}5.23 \pm \\
0.67\end{array}$ & $\begin{array}{c}7.03 \pm \\
0.27\end{array}$ & $\begin{array}{c}4.09 \pm 0 \\
.309\end{array}$ & $\begin{array}{c}5.59 \pm \\
0.23\end{array}$ \\
\hline $\begin{array}{l}\text { Creatinine } \\
\mu \mathrm{mol} / \mathrm{L}\end{array}$ & $\begin{array}{l}39.6- \\
160.0\end{array}$ & $\begin{array}{c}114.40 \pm \\
10.71\end{array}$ & $\begin{array}{c}116.47 \pm \\
4.69\end{array}$ & $\begin{array}{c}94.13 \pm \\
4.27\end{array}$ & $\begin{array}{c}126.13 \pm \\
4.86\end{array}$ \\
\hline $\begin{array}{l}\text { BUN/Crea } \\
\text { tinine }\end{array}$ & - & 45.7 & 60.4 & 43.5 & 44.3 \\
\hline $\begin{array}{l}\text { Glucose, } \\
\mathrm{mmol} / \mathrm{L}\end{array}$ & $2.2-3.3$ & $\begin{array}{c}3.55 \pm \\
0.26\end{array}$ & $\begin{array}{c}3.34 \pm \\
0.21\end{array}$ & $\begin{array}{c}3.32 \pm 0 \\
.13\end{array}$ & $\begin{array}{c}4.57 \pm \\
0.04\end{array}$ \\
\hline $\begin{array}{l}\text { Billirubin, } \\
\mu \mathrm{mol} / \mathrm{L}\end{array}$ & $\begin{array}{c}0.17- \\
5.1\end{array}$ & $\begin{array}{c}3.37 \pm \\
0.37\end{array}$ & $\begin{array}{c}3.63 \pm \\
0.06\end{array}$ & $\begin{array}{c}3.60 \pm 0 \\
.15\end{array}$ & $\begin{array}{c}2.60 \pm \\
0.10\end{array}$ \\
\hline $\begin{array}{l}\text { Cholester } \\
\text { ol, } \\
\mathrm{mmol} / \mathrm{L}\end{array}$ & $\begin{array}{l}1.3- \\
4.42\end{array}$ & $\begin{array}{c}2.76 \pm \\
0.16\end{array}$ & $\begin{array}{c}2.69 \pm \\
0.32\end{array}$ & $\begin{array}{c}2.57 \pm 0 \\
.34\end{array}$ & $\begin{array}{c}2.78 \pm \\
0.16\end{array}$ \\
\hline $\begin{array}{l}\mathrm{ALT}, \\
\mathrm{mmol} / \mathrm{L} * \mathrm{~h}\end{array}$ & $0.2-0.7$ & $\begin{array}{c}0.83 \pm \\
0.11\end{array}$ & $\begin{array}{c}0.77 \pm \\
0.07\end{array}$ & $\begin{array}{c}0.77 \pm 0 \\
.08\end{array}$ & $\begin{array}{c}0.58 \pm \\
0.04\end{array}$ \\
\hline $\begin{array}{l}\mathrm{AST}, \\
\mathrm{mmol} / \mathrm{L} * \mathrm{~h}\end{array}$ & $0.3-1.3$ & $\begin{array}{c}1.20 \pm \\
0.17\end{array}$ & $\begin{array}{c}1.38 \pm \\
0.13\end{array}$ & $\begin{array}{c}1.31 \pm 0 \\
.10\end{array}$ & $\begin{array}{c}1.23 \pm \\
0.11\end{array}$ \\
\hline ALT/AST & - & 0.69 & 0.56 & 0.59 & 0.47 \\
\hline $\begin{array}{l}\text { Carotene, } \\
\mathrm{mg} \%\end{array}$ & $0.4-1.0$ & $\begin{array}{c}0.42 \pm \\
0.02\end{array}$ & $\begin{array}{l}0.41 \pm \\
0.003\end{array}$ & $\begin{array}{c}0.39 \pm 0 \\
.007\end{array}$ & $\begin{array}{l}0.41 \pm \\
0.007\end{array}$ \\
\hline $\begin{array}{l}\text { Ketone } \\
\text { bodies, } \\
\mathrm{mg} \%\end{array}$ & $1-6$ & $\begin{array}{l}\text { Within } \\
\text { the } \\
\text { normal } \\
\text { values }\end{array}$ & $\begin{array}{l}\text { Within } \\
\text { the } \\
\text { normal } \\
\text { values }\end{array}$ & $\begin{array}{l}\text { Within } \\
\text { the } \\
\text { normal } \\
\text { values }\end{array}$ & $\begin{array}{l}\text { Within } \\
\text { the } \\
\text { normal } \\
\text { values }\end{array}$ \\
\hline
\end{tabular}

Proteins contained in the blood are responsible for the homeostasis of blood $\mathrm{pH}$, the content of ions, and oncotic pressure. They play an important role in the immune protection of the organism, take part in the synthesis of complexes with carbohydrates, lipids, and hormones. Hypoproteinemia is observed in underfed animals that have alimental dystrophy, chronic gastrointestinal disorders, and hepatic and renal pathologies. Hyperproteinemia is observed more often in the conditions of intensive farming, and as a rule, indicates protein overdose, ketosis, and toxicoses [15]. In the present study, in all the groups, the content of total protein was within the norm. Its highest concentration close to the upper borderline of the line was revealed in one-calf heifers (Group III), and the lowest - in heifers from Group IV.

It was established that in Group II, the level of BUN was elevated by $4.7 \%$ in comparison with the reference values. The lowest values were revealed in Group III. It is known that urea is the main final product of protein metabolism (processing of toxic ammonia in the liver). Ammonia is formed in the organism continuously during the process of non-oxidative and oxidative deamination, degradation of purine and pyrimidine bases, amid hydrolysis of glutamine and asparagine acids [16]. An increase in the level of urea can be associated with excessive content of proteins in the diet and reflect a high rate of their ingestion. On the contrary, a decreased level of urea in blood is not a negative sign in the majority of cases. Another parameter of protein metabolism is creatinine. In all the groups, it was within the norm. The highest level of creatinine was revealed in animals from Group IV, and the lowest - in Group III. The majority of creatinine is formed in the liver and then transported to the skeletal muscles. High levels of creatinine in the blood are also revealed in animals with kidney impairments that cause parenchyma damage and a decrease in the rate of glomerular filtration.

The most important diagnostic parameter is the $\mathrm{BUN} /$ creatinine ratio. This ratio characterizes the functional condition of the kidneys and the rate of glomerular filtration. An increase in the index indicates the presence of pathological processes in the kidneys. In the norm, the urea is filtered and excreted by the kidneys. The highest index was revealed in Group II, which indicates a higher risk of kidney and liver disorders among heifers. Besides, the condition of the liver reflects the content of bilirubin (bile pigment) that is formed as a result of the degradation of proteins that contain hem and cytochromes. The high content of bilirubin is observed in animals with damaged liver parenchyma, increased hemolysis of erythrocytes, and disturbance of the bile outflow to the intestine. In the tested animals, the authors did not reveal deviations in the content of bilirubin from the reference values.

Due to intensive adaptive processes and mobilization of the organism resources, animals from Group I and IV revealed an increased level of glucose in the blood by $7.6 \%$ and $38.5 \%$, respectively. Short-term hyperglycemia is typical in stressed animals. Besides, there were no deviations in lipid metabolism, which indicated favorable adaptation of animals.

In some groups of animals, the activity of serum enzymes increased. In Group II and III, the activity of alanine aminotransferase (ALT) was higher than normal values by $9.1 \%$, and in Group I, by $15.7 \%$. The activity of aspartate aminotransferase (AST) was higher by $5.8 \%$ in heifers from Group II. The indices of transaminases in all the groups revealed no serious pathology. ALT and AST provide reversible reactions of transfer of amino groups between amino acids and ketoacids. During the development of pathological processes, the specified enzymes are released from the damaged cells and their concentration in the blood serum significantly increases. A moderate increase in the activity of these enzymes indicates the activation of metabolic processes in the organism. A high ratio ALT/AST indicates liver damage [17].

Cholesterol is contained in the membranes of tissues. It is a component of lipoproteins in blood and acts as a precursor in the synthesis of vitamin $\mathrm{D}$ and steroid hormones. The major part of cholesterol is used for the synthesis of bile acids. The disturbance of the processes of fat oxidation is associated with increased production of ketone bodies that negatively affect 
(inhibit) the CNS. This is accompanied by the impairments of blood circulation and breathing. In cows, difficult delivery and labor paresis are observed. Animals that had diseases associated with an elevated level of ketone bodies often become infertile. Calves are born with decreased viability and often die within the first days after the birth [18]. In the present study, the levels of cholesterol and ketone bodies showed that the lipid metabolism was normal.

The content of the main precursor of Vitamin A required for normal growth and reproduction was within the lower borderline of the norm in all the groups.

The authors also studied the parameters of the mineral metabolism for a complete evaluation of animal health and the characteristics of metabolic processes during adaptation (Table 2).

The quality of mineral metabolism in imported cattle was characterized by moderate deviations in the levels of separate elements in some groups. However, it was noted that the level of calcium in the serum was within the norm and at the same level in all animals. This element influences numerous biochemical and physiological processes in animals: regulates blood coagulation, takes part in the transmission of nervous impulses, molecular mechanism of muscle contraction, secretory and incretory processes of the digestive and endocrine glands. A high requirement of this element is typical for highly productive animals during lactation. Calcium is essential in the structure of bone tissue, exerts anti-stress, anti-inflammatory, and desensibilizing properties [19, 20].

Table 2. Parameters of mineral metabolism in the Belgian breed bovine cattle

\begin{tabular}{lccccc}
\hline $\begin{array}{l}\text { Para } \\
\text { meter }\end{array}$ & $\begin{array}{c}\text { Refer } \\
\text { ence } \\
\text { value } \\
\text { s }\end{array}$ & $\begin{array}{c}\text { Group } \\
\text { I }\end{array}$ & $\begin{array}{c}\text { Group } \\
\text { II }\end{array}$ & $\begin{array}{c}\text { Group } \\
\text { III }\end{array}$ & $\begin{array}{c}\text { Group } \\
\text { IV }\end{array}$ \\
\hline Total & & & & & \\
calciu & $2.5-$ & $2.58 \pm$ & $2.57 \pm$ & $2.55 \pm$ & $2.57 \pm$ \\
m, & 3.1 & 0.083 & 0.044 & 0.029 & 0.06 \\
mmol/ & & & & & \\
L & & & & & \\
Iron, & $35-45$ & $35.08 \pm$ & $36.16 \pm$ & $30.60 \pm$ & $31.60 \pm$ \\
mg & & 0.54 & 1.05 & 0.61 & 0.69 \\
Manga & & $10.87 \pm$ & $5.58 \pm$ & $6.43 \pm$ & $6.92 \pm$ \\
nese, & $2-20$ & 3.91 & 0.44 & 0.54 & 0.27 \\
$\mu g$ & & & & & \\
Coppe & $80-$ & $120.52 \pm$ & $100.12 \pm$ & $87.49 \pm$ & $146.77 \pm$ \\
r, $\mu \mathrm{g}$ & 120 & 6.15 & 12.20 & 0.36 & 22.89 \\
Zinc, & $200-$ & $386.02 \pm$ & $290.16 \pm$ & $289.73 \pm$ & $326.51 \pm$ \\
$\mu \mathrm{g}$ & 400 & 30.56 & 3.79 & 14.27 & 31.61 \\
\hline
\end{tabular}

The level of iron was lower than reference values in one-calf heifers in Group III and in heifers in Group IV by $14.4 \%$ and $10.8 \%$, respectively. Iron is known to provide the functions of hemoglobin and myoglobin. It is contained in the structure of such enzymes as xanthine oxidase, succinate dehydrogenase, acetyl-CoA, and formate dehydrogenase that maintain metabolic processes. It was established that in Group II, the level of copper was within the upper borderline of the norm. In Group IV, it was higher than the norm by $18.2 \%$. Iron is contained in the structure of hem, antioxidant protein ceruleoplasmin, and co-enzymes. The lack of copper leads to osteodystrophy and anemia. Primarily, hypoelementosis affects the synthesis of oxalating enzymes, provokes the disturbances of lipid metabolism, synthesis of chromoproteins, proteins, and oxidation of substrates in the cycle of tricarboxylic acids. The excess of copper is accumulated in the liver, provokes the development of "copper hepatitis" and an increase in the level of bilirubin. The revealed deviations in the mineral metabolism are observed due to the activation of iron and copper-dependent enzyme systems, intensification of oxygenation of tissues, an increase in the synthesis of hemoglobin.

The concentration of other microelements (manganese and zinc) was within the norm despite the increased requirement during a transfer of cows and heifers from the interlactation period to lactation and in stressed animals. The elements exert different functions in the composition of enzymes. For example, they are included in the structure of isoforms of antioxidant enzymesuperoxide dismutase that also includes copper. A high consumption rate of microelements in one-calf heifers can be explained by the establishment of lactation and increase in the synthesis of metalloproteins [21].

It should be mentioned that insignificant deviations in the blood parameter values from the norm in one-month-old heifers from Group IV indicate a good level of adaptation of their mothers to new conditions according to the peculiarities of the system "mother-progeny" [22].

The analysis of the condition of the adapted animals based on the biochemical blood parameters provides the data on the adaptation of animals to new conditions. Its advantages include quickness and availability for larger husbandries. Still, this method should not be used alone. Depending on the influencing factor or groups of factors that underwent the most significant changes, the respective response reactions of the animals should be evaluated.

\section{CONCLUSION}

The analysis of biochemical blood and mineral metabolism assays showed deviations from the norm in all the groups. Such deviations were observed in protein, carbohydrate, enzymatic, and mineral metabolism but they were typical for heifers in the process of adaptation to conditions of the Voronezh Region. A positive sign was a complete lack of deviations in lipid metabolism. It was shown that animals from Groups I and IV did not experience microelement deficiency because of lack of pregnancy or the beginning of lactation.

The authors did not reveal any critical deviations that could manifest the development of serious pathological processes even in one-month-old heifers, which indicated the favorable condition of the progeny received in the Voronezh Region and their mothers.

The results of the study showed a successful adaptation process and the possibility of new livestock to realize their genetic potential on the territory of the Chernozem Region of the Central Federal District of Russia. 
The capability of the Belgian breed to adapt successfully to the conditions of the Voronezh Regions and to produce healthy progeny confirms the feasibility of importing cattle for selection and production purposes.

The study of biochemical and elemental composition of the blood can be used in the evaluation of cow and heifer adaptation. Besides, a detailed study of the adaptation process of the imported large bovine cattle to the new conditions will include the continuation of the study of biochemical blood parameters in further generations, parameters of peroxide lipid oxidation, the system of antioxidant protection, and productive characteristics on lager samplings.

\section{References}

[1] I. A. Shkuratova, N. A. Vereshchak, M. V. Ryaposova, O. S. Bodrova and I. U. Vershinina, "The immune status correction in highly productive cows". Veterinarni Medicina, vol. 2, p. 11, 2008.

[2] R. A. Eigenberg, T. M. Brown- B., J. A. Nienaber, "Development of a livestock weather safety monitor for feedlot cattle". Applied Engineering in Agriculture, vol. 23(5), pp. 657-660, 2007.

[3] D. Samir, "Impact of Climate Change on Livestock, Various Adaptive and Mitigative Measures for Sustainable Livestock Production". Appro Poult Dairy \& Vet Sci, vol. 1(4), APDV.000517, 2017.

[4] W. S. Kim, J.-S. Lee, S. W. Jeon, D. Q. Peng, Y. S. Kim, M. H. Bae, Y. H. Jo, H. G. Lee, "Correlation between blood, physiological and behavioral parameters in beef calves under heat stress". Asian-Australasian Journal of Animal Sciences, vol. 31, no. 6, pp. 919-925, 2018.

[5] V. A. Safonov, "Metabolic profile of highly productive pregnant and infertile cows". Agricultural biology, vol. 43, no. 4, pp. 64-67, 2008.

[6] V. A. Safonov, A. G. Nezhdanov, M. I. Retskiy, S. V. Shabunin and G. N. Bliznetsova, "Free radical oxidation of lipids and reproductive health of cows". Agricultural biology, vol. 49, no. 6, pp. 107-115, 2014.

[7] I. Ventsova and V. Safonov, "The role of oxidative stress during pregnancy on obstetric pathology development in high-yielding dairy cows". American Journal of Animal and Veterinary Sciences, vol 16, no. 1, pp. 7-14, 2021.

[8] B. P. Mokhov and E. P. Shabalina, Adaptation of Bovine Cattle. Monography. Uliyanovsk: Stolypina USAA, 2013.

[9] T. K. Bekseitov, R. B. Abeldinov, Zh. M. Mukatayeva, "Study on the acclimatization qualities of imported cattle in the Republic of Kazakhstan". Archiva Zootechnica, vol. 19 (1), pp. 17-35, 2016.

[10] Smakuyev D., Shakmurzov M., Pogodaev V., Shevkhuzhev A., Rebezov M., Kosilov V., Yessimbekov Zh. "Acclimatization and productive qualities of American origin Aberdeen-Angus cattle pastured at the submontane area of the Northern Caucasus". Journal of the Saudi Society of Agricultural Sciences, 2021.

[11] L. P. Coriakina, A. I. Pavlova, N. N. Grogorieva and N. I. Borisov, "Morphological indices of blood of imported cattle breed kholmogory in the process of adaptation to the conditions of Yakutia". Innovations and production safety, no. 3, pp. 89-94, 2017.
[12]P. Herbut, S. Angrecka, J. Walczak, "Environmental parameters to assessing of heat stress in dairy cattle-a review". International journal of biometeorology, vol. 62, no. 12, pp. 2089-2097, 2018.

[13]K. Plemyashov, G. Nikitin, A. Nikitina, S. Kovalev, V. Trushkin, P. Anipchenko, A. Votinceva and A. Batrakov, "Hematological status of newly-calved cows with mineral metabolism disturbance". FASEB Journal, vol. 33, no. S1, p. lb374, 2019.

[14] S. P. Kovalev, Clinical Evaluation of Hematological Studies in Agricultural Animals. Methodical guidelines. $\mathrm{Spb}, 2004$.

[15] L. Y. Karpenko, A. I. Enukashvili and A. A. Bakhta, "The dynamics of the parameters of non-specific resistance in the bovine cattle depending on the physiological condition”. Medical Immunology, vol. 13, no. 4-5, p. 547, 2011.

[16] J. Marczuk, P. Brodzki, A. Brodzki, Ł Kurek, "The concentration of free amino acids in blood serum of dairy cows with primary ketosis". Polish journal of veterinary sciences, vol. 21, no 1, pp. 149-156. 2018.

[17]D. J. Jones, "Stability and storage characteristics of enzymes in cattle blood". Research in Veterinary Science, vol. 38, no. 3, pp. 301-306, 1985.

[18] K. Moiseeva, P. Anipchenko, S. Vasil'eva, L. Karpenko, R. Vasil'ev, N. Pilaeva, A. Bakhta, N. Panova, V. Thrushkin, G. Nikitin, A. Nikitina and O. Ershova, "Dynamics of cholesterol and triglycerides in the serum of cows with liver lipidosis". Journal of Animal Science, vol. 97, no. S3, p. 208, 2019.

[19]I. V. Gusev, R. A. Rykov, "Reference intervals of biochemical blood parameters for control of usefulness of dairy cattle feeding". Dairy and beef cattle breeding, iss. 9 pp. 22-25, 2018.

[20] L. L. Hernandez, "New insights into calcium intake in transition dairy cattle". Journal of Animal Science, vol. 95, iss. suppl. 2, p. 28, 2017.

[21]D. Wysocka, A. Snarska, P. Sobiech, "Copper - an essential micronutrient for calves and adult cattle". Journal of Elementology. vol. 24, no 1, pp. 101-110, 2019

[22] T. M. Ushakov, T. N. Derezina, I. V. Kapelist and G. A. Zelenkova, "Correlation of essential microelements in the bovine cattle in the system "mother-progeny" as a factor of the development of immune depressive condition". Kuban veterinary, no. 3, pp. 6-9, 2020.

\section{Creative Commons Attribution License 4.0 (Attribution 4.0 International , CC BY 4.0)}

This article is published under the terms of the Creative Commons Attribution License 4.0 https://creativecommons.org/licenses/by/4.0/deed.en US 